\title{
Climatic Conditions and Experience of Operation of Port Facilities on Sakhalin Island
}

\author{
Malyuk VV* \\ Sakhalin State University, Transstroy-Test, LLC Yuzhno-Sakhalinsk, Russia
}

Submission: August 31, 2020; Published: September 24, 2020

*Corresponding author: Malyuk VV, Sakhalin State University, Transstroy-Test, LLC Yuzhno-Sakhalinsk, Russia

Abstract

The article provides an analysis of the operating conditions of port facilities in heavy hydrometeorological conditions on the coast of Sakhalin Island to establish durability characteristics for the development of design life models. Typical types of concrete destruction in the zone of variable level are considered. The directions of research in the field of forecasting the durability of concrete and reinforced concrete structures for seaport facilities on actual durability characteristics are outlined.

Keywords: Concrete; Durability; Sea port facilities

\section{Introduction}

The modern design concept of construction facilities according to operational characteristics implies a variable approach to the assignment of requirements to structures and materials for structures, which should guarantee the predicted service life while maintaining the economic feasibility of the service life [1]. The principle of this design approach is set out and recommended for application in ISO 15686. This document is developed on the regulatory basis and practical studies conducted in the UK, Japan, Canada, the USA and the EU countries. Currently, the approach to designing the durability of structures according to performance characteristics is planned to be used in Russia [2]. Obviously, the difference in the regulatory framework and the variety of climatic conditions of Russia is the main obstacle to the direct application of ISO 15686 in the design of construction projects in Russia. This article contains the results of a preliminary survey of the operating conditions of port facilities on Sakhalin Island.

Berthing facilities on the southern coast of Sakhalin are operated in difficult hydrometeorological conditions, which are most clearly manifested in the winter. The specificity of climatic conditions, which is due to the influence of the cold Okhotsk and warm Sea of Japan, creates, on the one hand, mild conditions for shipping - the port area does not freeze, on the other, harsh operating conditions for concrete: during four winter months, the concrete structure of port facilities in the variable level zone is subject to various freezing conditions. In accordance with the international and Russian classification of aggressiveness of media [1, 3], these conditions belong to the most severe class - XF4 (strong water saturation in seawater and the effect of freezing). Hydrometeorological conditions of the southern part of Sakhalin are characterized by the following indicators [4]. The sea in winter is the most turbulent - the average repetition of excitement is 35$50 \%$, the height of the waves reaches 4-6 m. Tides are complex, but there are two main types: daily and mixed. The tidal wave enters from the south and southeast of the Pacific Ocean. In the southern part of the island, the tides are 0.8-2.5 m. In winter, the water temperature on the sea surface is about $0{ }^{\circ} \mathrm{C}$. Salinity of water on the surface 31-33\%. Small meters and jokes in January and February are almost absent, the wind speed is usually 10-11 $\mathrm{m} / \mathrm{s}$. Design winter temperature of external air $17-19{ }^{\circ} \mathrm{C}$ below zero [3]. A significant difference in the operating conditions of concrete in the zone of variable level makes it possible to trace the influence of three characteristic processes that occur during freezing:

a. slow one-way freezing of concrete of massive structures with gradual advance of the front into the concrete depth

b. quick comprehensive freezing of concrete of thin-walled structures with formation of ice in surface layers and blockage of water inside the structure

c. one-way freezing of porous material, in which it is possible to migrate water in a vapor-like state to a cold surface and form ice lenses by analogy of soil swell. 


\section{Civil Engineering Research Journal}

The pictures show the operating conditions of concrete of port facilities in the zone of variable level (Figure $1 \mathrm{a}, \mathrm{b}, \mathrm{c}$ ) and characteristic damages of concrete (Figure 2 a,b,c,d,e,f). The variety of damage types even in one structure (see Fig. 2) confirms the variety of factors and mechanisms of destruction. Thus, lifecycle patterns for a single design can vary significantly. This is a major challenge for developing simple life prediction models of concrete for practical applications. The study of the state of real structures is the basis for determining the dominant factors affecting the durability of concrete and determining durability in frost conditions. In the Far East of Russia there is extensive experience in the construction of offshore structures from "classical" (without additional) concrete and "modern" concrete, made using structure-forming additives $[5,6]$. In the first case, there are structures whose service life is 100 years, in the second - the service life approaches 50 years. This experience has been studied for 50 years and is, as a rule, the basis for the development of new technological solutions [7] and proposals for modeling the durability of concrete [8.9].
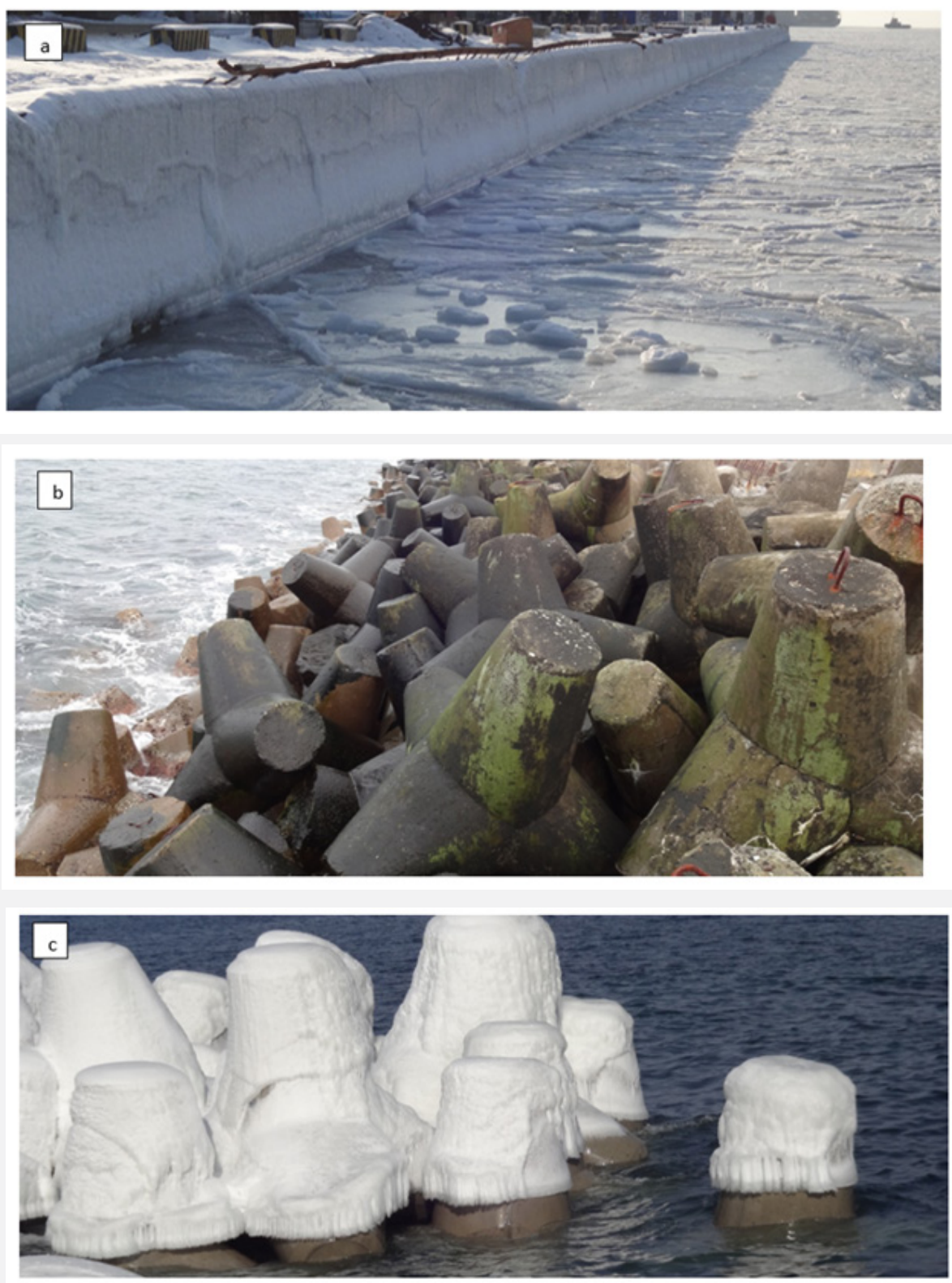

Figure 1: Operation conditions of concrete in the area of variable level of port facilities: massive mooring (a) and fencing (b, c) from shaped massifs (tetrapods). 


\section{Civil Engineering Research Journal}
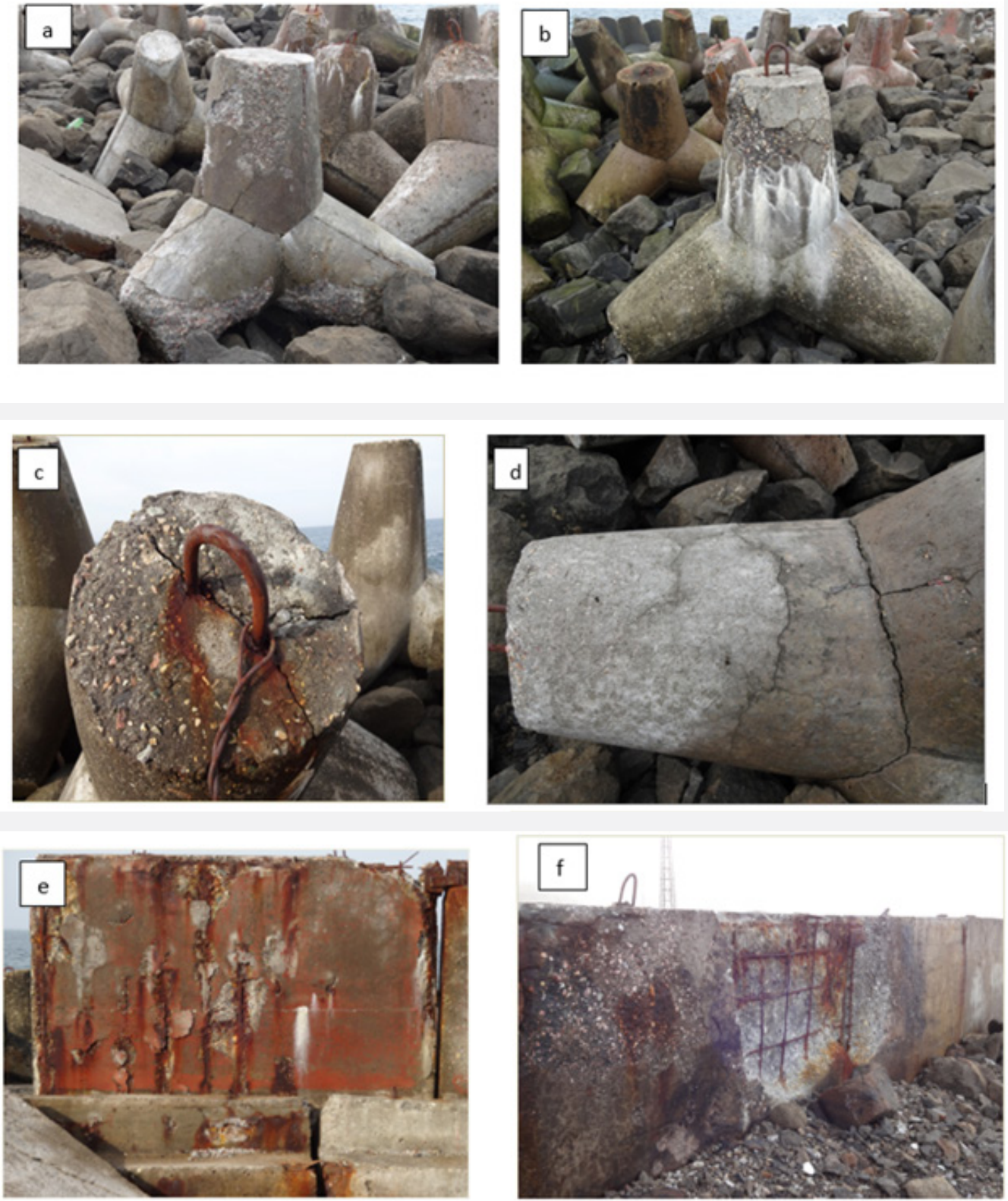

Figure 2.: Characteristic destructions of concrete in a zone of variable level: superficial and volume destructions (a, b), the destructions connected with corrosion of fittings (c, d, e), disclosure of technological cracks (f).

The special climatic conditions of the southern coast of Sakhalin, the variety of types of port facilities, the long life of the facilities and the variety of technological solutions for the production of concrete works create a unique basis for fullscale studies of the durability of concrete in order to develop mathematical models for designing the facilities according to operational characteristics. Mathematical constructions should be based on deeply studied of physical and physicochemical phenomena of concrete corrosion. Therefore, for the construction of mathematical models, it is important to establish the patterns of concrete degradation in real operating conditions of structures and to determine indicators characterizing the durability of concrete in operating conditions.

\section{References}

1. (2015) Performance-Based Specifications and Control of Concrete Durability: State-of-the-Art Report RILEM TC 230-PSC (RILEM Stateof-the-Art Reports (18) Springer; $1^{\text {st }}$ ed. 2016 edition pp: 391. 


\section{Civil Engineering Research Journal}

2. (2014) Stepanova VF, Falikman VP (2014) Modern problems of ensuring the durability of reinforced concrete structures. Scientific works of III All-Russia (II International) Conference on Concrete and Reinforced Concrete, Concrete and reinforced concrete - a look into the future. Reinforcing bars and the system of reinforcement. FRC and armoured cement. Issues of durability. Moscow: MCEI-MSCU pp: 464.

3. (2018) GOST 31384-2017 Protection of concrete and reinforced concrete structures against corrosion. General technical requirements - Incorporated.

4. (1998) Hydrometeorology and hydrochemistry of the seas: Volume IX. Sea of Okhotsk. Issue. 1. Hydrometeorological conditions/ edited by Glukhovsky BH, Goptarev NP, Terzieva FS. Petersburg S: Hydrometeoizdat pp: 342 .

5. Sviridov VN, Malyuk VD (2014) Assessment of the durability of concrete in structures of maritime facilities based on the experience of construction in the Far East. Scientific works of III All-Russia (II International) Conference on Concrete and Reinforced Concrete, Concrete and reinforced concrete - a look into the future", Moscow: MCEI-MSCU, pp: 388-398.
6. Sviridov VN, Malyuk VD (2008) Application of High Frost-Resistance Concrete Technology in the Practice of Marine Hydrotechnical Construction in the Far East. Incorporated in collected works «Environment. Construction. Safety» (Vladivostok: Dalnauka) pp: 233236.

7. Royak GS, Sviridov VN, Malyuk VD (2012) Portland blast-furnace cement for high durability concrete based on local building materials (about strength of Portland blast-furnace cement-based concrete in marine structures). Proceedings of International Conference on Building Materials, 18. ibausil, Vol.2, Weimar, Germany, ISBN 978-300-034075-8 pp:747-753.

8. Leonovich SN, Litvinovsky DA, Chernyakevich You, Stepanova AV (2016) Strength, Crack-Resistance and Durability of Structural Concrete at Temperature and Corrosion Impacts /: monograph in 2 parts vol 2 (Minsk: publishing house BNTU) pp:393.

9. Malyuk V (2019) Prognostication of concrete constructions durability based on experience in building and exploitation of maritime coastprotecting structures on Sakhalin Island (on the issue of determining the estimated lifetime of maritime structures), MATEC Web of Conferences. Volume 265: 02014.

\begin{tabular}{l} 
Your next submission with Juniper Publishers \\
will reach you the below assets \\
- Quality Editorial service \\
- Swift Peer Review \\
- Reprints availability \\
- E-prints Service \\
- Manuscript Podcast for convenient understanding \\
- Global attainment for your research \\
- Manuscript accessibility in different formats \\
( Pdf, E-pub, Full Text, Audio) \\
- Unceasing customer service \\
Track the below URL for one-step submission \\
https://juniperpublishers.com/online-submission.php \\
\hline
\end{tabular}

